NBER WORKING PAPER SERIES

\title{
AN INSTITUTIONAL THEORY OF PUBLIC CONTRACTS: REGULATORY IMPLICATIONS
}

\author{
Pablo T. Spiller \\ Working Paper 14152 \\ http://www.nber.org/papers/w14152 \\ NATIONAL BUREAU OF ECONOMIC RESEARCH \\ 1050 Massachusetts Avenue \\ Cambridge, MA 02138 \\ August 2008
}

Jeffrey A. Jacobs Distinguished Professor of Business and Technology, Haas School of Business, University of California, Berkeley, and Research Associate, NBER. This paper benefited from comments received at various workshops and seminars, including the World Bank, the Nice Conference on Regulation and Deregulation, University of California, Irvine, and ISNIE, as well as from an anonymous referee and from conversations with Benito Arruñada, Bryan Hong, Claude Menard, Robert Seamans, Steve Tadelis, Richard Wang, and Oliver Williamson. Bryan Hong, Richard Wang and Robert Seamans provided useful research assistance. This research benefited from funding from the Jeffrey A. Jacobs Distinguished Professorship Chair in Business and Technology at the Haas School of Business of the University of California, Berkeley. I can be contacted at spiller@haas.berkeley.edu. The views expressed herein are those of the author(s) and do not necessarily reflect the views of the National Bureau of Economic Research.

NBER working papers are circulated for discussion and comment purposes. They have not been peerreviewed or been subject to the review by the NBER Board of Directors that accompanies official NBER publications.

(C) 2008 by Pablo T. Spiller. All rights reserved. Short sections of text, not to exceed two paragraphs, may be quoted without explicit permission provided that full credit, including $\bigcirc$ notice, is given to the source. 
An Institutional Theory of Public Contracts: Regulatory Implications

Pablo T. Spiller

NBER Working Paper No. 14152

August 2008

JEL No. H11,L14,L32,L33,L51

\begin{abstract}
$\underline{\text { ABSTRACT }}$
The fundamental feature of private contracting is its relational nature. When faced with unforeseen or unexpected circumstances, private parties, as long as the relation remains worthwhile, adjust their required performance without the need for costly renegotiation or formal recontracting. Public contracting, on the other hand, seems to be characterized by formalized, standardized, bureaucratic, rigid procedures. Common wisdom sees public contracts as generally more inflexible, requiring more frequent formal renegotiation, having a higher tendency to litigate, and providing weaker incentives. In sum, public contracts are perceived to be less "efficient." In this paper I develop a theory of public contracting that accommodates these stark differences between private and public contracting. The thrust of the paper is that these differences arise directly because of the different hazards present in public and purely private contracts, which directly impact the nature of the resulting contractual forms. A fundamental corollary of this result is that the perceived inefficiency of public or governmental contracting is simply the result of contractual adaptation to different inherent hazards, and as such is not directly remediable. Finally, I apply the main insights from the general framework developed here to understand the characteristics of concession contracts.
\end{abstract}

Pablo T. Spiller

University of California

Walter A. Haas School of Business

Faculty Bldg. 593

Berkeley, CA 94720

and NBER

spiller@haas.berkeley.edu 
The fundamental feature of private contracting is its relational nature. ${ }^{1}$ When faced with unforeseen or unexpected circumstances, private parties, as long as the relation remains worthwhile, adjust their required performance without the need for costly renegotiation or formal recontracting (Baker et al 2001). ${ }^{2}$ Public contracting, ${ }^{3}$ on the other hand, seems to be characterized by formalized, standardized, bureaucratic, rigid procedures (Greenstein 1993). ${ }^{4}$ Faced with unexpected circumstances, parties in a public contract may face, even when the relation remains worthwhile, the stark choice of litigation or performance. In fact, common wisdom sees public contracts as generally more inflexible, requiring more frequent formal renegotiation, having a higher tendency to litigate, and providing weaker incentives. In sum, public contracts are perceived to be less "efficient."

The main thrust of this paper is twofold: first, just as in private contracting, the nature of contracting hazards is what determines the fundamental features of public contracting (Williamson 1979). A fundamental difference between private and public contracts is that public contracts are in the public sphere, and thus, although politics is normally not necessary to understand private contracting, ${ }^{5}$ it becomes fundamental to understanding public contracting. Second, the analysis of public contracting must be done within the

\footnotetext{
${ }^{1}$ See, e.g., Mccaulay (1963), McNeil (1974), Williamson (2002).

${ }^{2}$ Corporations, however, often move away from relational contracting endorsing highly formalized contracting procedures, only to reverse course. A case in point is GM's recent endorsement, jointly with the US Department of Defense, of highly bureaucratized IT procurement practices, the Capability Maturity Model Integration. See Bernard et al (2004). See also CIO.com report at http://www.cio.com/article/156400/New_Guidelines_for_IT_Procurement_May_Prove_Intimidating.

${ }^{3}$ Hereafter, I refer to public contracting to the case when one of the parties to a transaction is a public entity, such as a governmental agency or company.

${ }^{4}$ Although there is a large literature dealing indirectly with what I call public contracting (such as the literature on privatization of municipal services or bureaucracy), there is in fact no systematic study I know of comparing public v. private contracts on the dimensions mentioned here.

5 There is a large literature on influence in organizations, which started with the work of Milgrom and Roberts (1988). See, generally, Laffont and Tirole (1993).
} 
proper institutional comparison (Coase 1964) and with a heavy micro-analytic dose (Williamson 1979). In fact, the supposed inefficiency of public contracting must be assessed in reference to all relevant alternatives (Williamson 1996).

In this paper I develop a theory of public contracting that accommodates these stark differences between private and public contracting. The thrust of the paper is that these differences arise directly because of the different hazards present in public and purely private contracts, which directly impact the nature of the resulting contractual forms. A fundamental corollary of this result is that the perceived inefficiency of public or governmental contracting is simply the result of contractual adaptation to different inherent hazards, and as such is not directly remediable (Williamson 1999). Finally, I apply the main insights from the general framework developed here to understand the characteristics of concession contracts.

\section{The Fundamental Benchmark: Private Contracting}

I start from the fundamental point that contracts are always incomplete, and that, to a large extent, the degree of incompleteness is chosen by the parties. In the extreme, and in the absence of a third party enforcer, contracts, whether explicit or implicit, may be sustained exclusively via implicit or explicit threats of actions, such as discontinuation of a relationship, ${ }^{6}$ executing implicit or explicit guarantees (Williamson 1983), decentralized enforcement by market participants (Milgrom et al 1990), or expelling the breaching party from membership in a clan, sect or family. ${ }^{7}$ In fact, even in the face of third party enforcement, companies normally rely on inter-firm relationships to support contracting

\footnotetext{
${ }^{6}$ A costly action if assets are not easily redeployed to alternative uses. See Telser (1981).

${ }^{7}$ See, for example, Greif (1993), Landa (1981), and Richman (2006).
} 
(Macaulay 1963), and in particular, on private ordering in a discriminating way

(Williamson 2002). Inter-firm relationships help manage conflicts that would otherwise be resolved via formal mechanisms (courts), with the corresponding uncertainties, delay and costs (Williamson 1975). MacNeil's (1978) three-way categorization of contracts into classical, neoclassical and relational properly highlights that as relations become long term and complex, the reference point for adaptations becomes less the original contract as specified, and more the entire relation as it developed, the "relational web" as Macneil (1974: 595) puts it. In fact, "adaptation is now taken to be the chief mission of economic organization," with cooperative adaptation being achieved via "complex contractual modes" (Williamson 2002).

Although informal and continuous adaptations may be enough to sustain a private contract over time, thereby reducing haggling and negotiating costs, they require the discriminating selection of governance structures, with "more complex modes of governance [being] reserved for more hazardous transactions" (Williamson 2002). Relational contracting, then, appears in highly complex transactions, transactions where parties have sunk highly specific investments (Williamson 1985), and where parties have highly particular, detailed and tacit knowledge of their specific situations, which they can use to "adapt to new information as it becomes available" (Baker et al 2002).

This, however, does not mean that formal adaptations and adjustments are not needed. In fact, large unexpected events may require wholesale re-contracting to provide further 
clarifications on how future adaptations will take place, or even termination of the relation. ${ }^{8}$

In sum, discriminating alignment is the foundation of private contract adaptability. The main risk facing the parties in complex transactions is opportunistic behavior by the trading party. Contractual governance is precisely designed to limit such behavior so as to successfully implement the transaction, or as Williamson (2002: 439) puts it, to "infuse order, thereby to relieve conflict, and realize mutual gain."

Figure 1 below reproduces Williamson's famous "simple contractual schema," whereby simple transactions $(\mathrm{k}=0)$ get implemented via simple contractual methods such as unassisted market transactions, while complex transactions $(k>0)$ exposing the parties to transaction hazards require the design of complex governance structures. Figure 1 shows the existence of multiple governance structures - credible contracting at node (C) and hierarchy at node (D) - which counter entering into the transaction with unrelieved hazards (node B).

\footnotetext{
${ }^{8}$ As Macaulay (1963: 65) represents, the use of courts is often relegated for the purpose of settling contract termination disputes, rather than contract adaptation.
} 
Figure 1: Williamson's Simple Contractual Schema

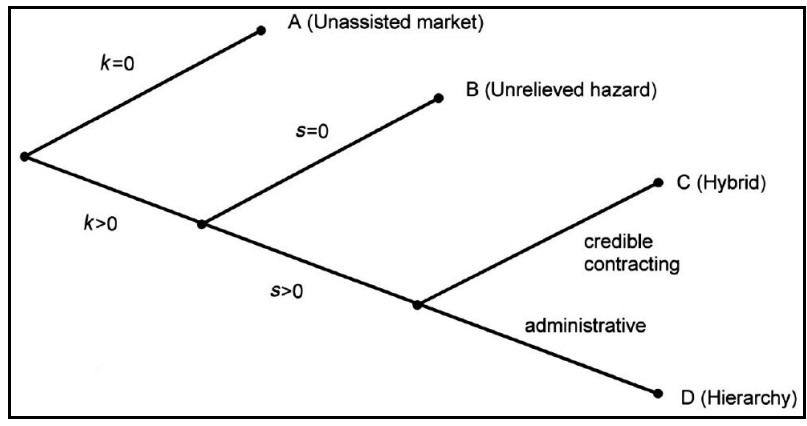

Source: Williamson (2005).

\section{Public Contracting}

Public contracting is exposed to a larger set of hazards than purely private contracting, arising from three fundamental types of opportunistic behavior. As in private contracting, parties with idiosyncratic investments face the risk of opportunistic behavior by its partner, whether public or private, and will thus attempt to design the transaction's governance so as to limit the risk of opportunistic behavior by its trading partner. I will call this, the risks associated to standard opportunistic behavior.

Public contracting, on the other hand, generates peculiar types of hazards associated with the fact that one of the parties to the contract is the state, or a state institution. Here I will focus on two hazards: governmental opportunism and third party opportunism. In previous writings, I emphasized governmental opportunism as the fundamental risk of investors in public utilities, ${ }^{9}$ and how regulation by contract may limit such risk. Regulation by contract requires, however, a judiciary that not only will see such a contract as property and thus that cannot unilaterally be modified by the government, but

\footnotetext{
${ }^{9}$ By governmental opportunism I refer to the ability of governments to opportunistically change the rules of the game once the utility sunk its investments. See, Spiller (1996a and 1996b), and Levy and Spiller (1994).
} 
also that will have the ability to enforce it. Facing these risks, then, private utilities may require that such regulatory contracts be highly specific, so as to limit opportunistic interpretations of contracts. In this paper I will briefly deal with governmental opportunism, ${ }^{10}$ and focus instead on what I believe is the fundamental risk faced by all public contracts -- third party opportunism.

\subsection{Public Contracting and Governmental Opportunism}

The risk of governmental opportunism arises because, differing from private actors, governments can opportunistically change the rules of the game via the standard use of governmental powers to extract the quasi-rents of its contract partner. ${ }^{11}$ Changes in the rules of the game can be done in multiple, subtle and not so subtle ways. Governments may issue legislation making illegal a particular type of contract, even a contract it may have originally designed. Such use of governmental powers may seem extreme, but is not unusual. Consider, for example, Venezuela's Decree No. 5.200/2007, ${ }^{12}$ requiring that PDVSA, the Venezuelan public oil company, take operational control over oil projects in Venezuela, cancel all exploration, commercialization and production rights of the private/public association agreements originally set up between PDVSA and private oil companies (where private investors were the majority shareholders) to explore and develop those oil fields, and transfer those rights to mixed companies controlled by PDVSA. This Decree, known as the Nationalization Decree, came after private oil

\footnotetext{
${ }^{10}$ For a more detailed treatment of governmental opportunism, see Spiller (1996 and an b).

${ }^{11}$ Spiller (1996a), Levy and Spiller (1994). This does not imply that the private contractor may not opportunistically withhold information, but such opportunism is of the "standard" nature, discussed at length by the literature.

12 Published on February 26, 2007, as Decreto Con Rango, Valor y Fuerza de Ley de Migración a Empresas Mixtas de los Convenios de Asociación de la Faja Petrolífera del Orinoco, así como de los Convenios de Exploración a Riesgo y Ganancias Compartidas.
} 
companies invested, by all accounts, billions of US dollars in developing these fields. ${ }^{13}$

One may imagine multiple reasons for Venezuela's government issuing the Nationalization Decree, but it may not be wild speculation that the Decree would not have been issued if crude oil prices would have stayed in the low 10s or 20s, rather than increased as they did starting in $2002 .^{14}$

Governmental opportunism, however, does not have to be so drastic as a law or Executive Decree cancelling or changing the nature of contracts, but can be achieved via the subtle works of administrative process. Consider, for example, the imposition of fines on a public utility for alleged quality deficiencies, or a regulatory decision denying a tariff increase. What may seem as innocuous acts of regulatory supervision, may actually be nothing else but governmental opportunism, attempting to extract part of the utility's quasi-rents. Consider, for example, the case of Compañía de Aguas del Aconquija, a water and sewage services concession granted by the Province of Tucumán, Argentina, in 1995 and terminated by the Province just two years later. The process that led to the contract termination, and described in unusual detail by the Arbitration Panel in its Award, ${ }^{15}$ is a textbook, and probably an extreme, example of what I call governmental opportunism, whereby a government uses its regulatory and executive powers to achieve a tariff reduction not allowed by the regulatory framework. In fact, the Aguas del Aconquija Award shows the multiplicity of instruments governments have at their

\footnotetext{
${ }^{13}$ See, for example, New York Times “2 Oil Firms Are Defiant in Venezuela.” June 27, 2007.

${ }^{14}$ The fact that other governments (such as Argentina, Bolivia and Ecuador) took similar or related actions following the rapid raise in the price of crude oil may indicate that Venezuela's Nationalization Decree may be better characterized as opportunistic rather than ideological.

${ }^{15}$ See, Award - "In the Arbitration between Compañia de Aguas del Aconquija S.A. and Vivendi Universal S.A. Claimants v. Argentine Republic, Respondent, Case No. ARB/97/3" issued on 20 August 2007.
} 
disposal to attempt to extract a utility's quasi-rents. In this case, the Provincial Government seems to have used all its formal powers - regulatory decisions, legislative acts, executive decrees, attorney general recommendations, even judicial decisions- and informal powers - press releases, Ombudsman's letters, public announcements, and the like-, to force the company's hand. ${ }^{16}$

Investors facing the risk of governmental opportunism will either not invest, or demand up-front compensation for that risk. Either strategy, however, as the case of Aguas del Aconquija shows, may not alleviate the risk, but rather may exacerbate it.

Government opportunism affects not only private investors but public operators as well. Since the government has direct control over publicly owned companies, Savedoff and Spiller (1999) explain how the threat of governmental opportunism against publicly owned companies may lead those companies to protect their cash flows against such hazards by undertaking actions, such as hiring too many permanent or transitory employees, granting excessive benefits, and the like, which translate into low efficiency and quality levels.

The limits to governmental opportunism are, however, institutional (Spiller 1996a and 1996b). The potential for the opportunistic use of legislative powers depends, to a large extent, on the control the executive may exercise over the legislature. Thus, a fragmented polity may provide more assurances to investors than a highly centralized government. Similarly, a judiciary with a tradition of independence may put some limits on

\footnotetext{
${ }^{16}$ At the end, the company attempted to rescind the contract due to Governmental breach, at which point the Province terminated the concession. The service remained in the company's hand for another year, at which point it was taken over by ENHOSA, a federal water service entity. See, Award, at page 112.
} 
opportunistic governmental behavior. Concession contracts, as long as they are upheld by the local courts, may also provide a level of commitment against opportunistic behavior. It is, thus, not surprising that the UK, a country characterized by a centralized government but with a long tradition of judicial independence, would have adopted a regulatory system based on concession contracts, while the regulatory structure in the US, a country characterized by fragmented government, is based on judicial review of administrative procedures (Spiller 1996a).

\subsection{Implications of Governmental Opportunism}

Facing the threat of governmental opportunism, private agents would require stronger safeguards to undertake contracts with the state than they would in contracts with other private agents. These safeguards may involve making the contract even more complete and more specific so as to avoid opportunistic interpretations or the transfer of some of the specific investments to the state.

In the absence of strong judicial independence, and of procedural safeguards, the threat of governmental opportunism may simply imply the payment of substantial upfront rents, or that the private sector may not contract with the state. Thus, in the absence of safeguards against governmental opportunism, public integration (whereby the government provides the service directly) and public ownership become equilibrium outcomes (Spiller and Levy 1994, Savedoff and Spiller 1999).

\subsection{Third Party Opportunism}

The essence of public contracting is its publicity. Public contracting involves, directly or indirectly, the use of public monies, and thus it affects, although indirectly, the lives of all 
citizens. Reasonably working societies, then, will naturally develop ways for public contracts to be subject to public scrutiny so as to avoid corruption and graft. ${ }^{17}$ Public contract scrutiny is normally undertaken by designated agencies in charge of contract supervision. In the United States, while individual departments have agencies in charge of auditing their procurement, the Office of Management and Budget, the Government Accountability Office, and the Congressional Budget Office routinely examine the procurement performance of government agencies and of the auditing agencies themselves. $^{18}$

Apart from official agencies, a substantial amount of supervision and control is done by interested third parties (McCubbins and Schwartz, 1984; McCubbins, Noll and Weingast 1987, 1989). ${ }^{19}$ In fact, McCubbins and Schwartz (1984) in their seminal article argue that politicians can manage the bureaucracy via "fire alarms," whereby interest groups (interested third parties) will "pull the alarm" when agencies stray from the politician's preferred policy path. They further make the point that "a predominantly fire-alarm oversight policy is likely to be more effective ... than a predominantly police-patrol policy." 20 Thus, third party supervision is fundamental in a democratic society.

\footnotetext{
${ }^{17}$ Private contracts, on the other hand, are normally protected against public scrutiny, often requiring a judicial act to make a private contract subject to public scrutiny. Some private contracts, however, are public for obvious reasons. The registration of land ownership requires the registration of real estate transactions, making some aspects of real estate transactions then potentially open to public scrutiny. ${ }^{18}$ For example, the Defense Contract Audit Agency, formed in 1965, is in charge of performing audits to all the US Defense Department contracts. The performance of the DCAA, in turn, is supervised by the $\mathrm{OMB}$, while the GOA and the CBO routinely review specific programs of the Department of Defense. See, for example, CBO, "Replacing and Repairing Equipment Used in Iraq and Afghanistan: The Army's Reset Program," Pub. No. 2809, September 2007; see also, GAO, Defense Acquisitions: Department of Defense Actions on Program Manager Empowerment and Accountability, November 9, 2007.

${ }^{19}$ de Figueiredo, Spiller and Urbiztondo (1999) also show that politicians prefer not only a proliferation of interested interest groups monitoring agencies, but also prefer them to come from divergent perspectives.

${ }^{20}$ McCubbins and Schwartz (1984: 171).
} 
A fundamental feature of interest groups as monitors, though, is that they are interested.

In other words, they are biased. They provide information only when it is to their advantage. That is, the third party (or parties) may behave opportunistically. As it relates to public contracts, interested third parties may have incentives to challenge the "probity" of a particular public agent when by such action they may benefit. Such incentives may exist when third parties compete with the public agent in another (political) market. Benefits may arise in the political and the economic sphere. In both it may involve the displacement of the incumbent (and competing) public agent. In the political sphere, the challenge may be deemed successful if because of the challenge the public agent is, eventually, replaced by an agent related or more to the liking of the interested third party. As it relates to the economic sphere, the challenge may be deemed successful if the private party is replaced or the terms of the contract are changed in ways that benefit the third party. But it is precisely because of competition in the political market that such challenges are particularly dangerous to the public agent. ${ }^{21}$

In a competitive political market environment third party opportunism, depending on the challenge's credibility, may entail significant costs to the public agent. The public agent may have to incur significant time and expense to defend its actions, ${ }^{22}$ may have to leave

\footnotetext{
${ }^{21}$ For example, the replacement of the private party may damage the political credibility of the incumbent public agent, weakening its position vis-à-vis a third party interested in its replacement.

${ }^{22}$ Public agents would not be expected to leave their positions without a (political) fight. Multiple interest groups may be expected to contribute to the public discussion following a challenge. Some groups, aligned with the beneficiaries of the particular contract or policy, may come to the public agent defense, and help to limit the effectiveness, or credibility, of the challenge (de Figueiredo et al 1999).
} 
its public position, or in the extreme, if the challenge is fully successful, may be prosecuted. $^{23}$

Given the inherent informational asymmetries between the interested third party, the courts, and the public in general, the challenge may be exercised even if the action is ethical and/or legal. In fact, the more complex the public/private transaction, the higher the inherent informational asymmetries, and thus, the higher the probability of third party opportunism.

The potential for successful challenges has different types of implications. Dal Bó and Di Tella (2006) show, for example, that the potential for threats of the type discussed here - that is, actions by third parties that may imply costs to public agents - impacts the selection of public agents. While the potential for positive transfers (i.e., bribes) increases the competition to become a public agent, the potential for costly and credible threats reduces it, thus reducing the quality of public agents. I will not explore this issue further here.

Here I will explore the impact that potential challenges of this sort have on the nature of public contracting in general. The exposure to third-party opportunism increases the risk to both the public agent and the private party contracting with the state. In response, both will have incentives to increase the specificity of these contracts as compared to equivalent contracts among private parties. Moreover, to mitigate the risk of third-party opportunism, these contracts are likely to demand more rigid procedural processes,

\footnotetext{
${ }^{23}$ This effect works also in non-democratic environments, as long as there is competition for political power.
} 
including formal procedures for renegotiation. Nevertheless, these adjustments are unlikely to mitigate third-party opportunism altogether, and the implementation of public contracts is more likely to experience a higher degree of conflict than contracts among private parties. In other words, the risk of third-party opportunism means that "relational" contracting is less likely to evolve in the public sphere.

\section{Related Literature}

Marshall, Meurer and Richard (1991 and 1994), for example, show that allowing excluded bidders to challenge the outcome of a procurement process inefficiently reduces sole-sourcing. Kelman (1990) reports that following the enactment in 1984 of the Competition in Contracting Act (CICA), one third of all major information technology federal procurements were protested including nearly all of the biggest procurements, leading to its reversal in 1995. Kelman (1990:155) further suggests that, in response, contract agents "think only about what's legally defensible. They bend over backwards to avoid appeals." Greenstein (1993) emphasizes the costs associated with procedural rules designed to increase transparency. For example, procurement rules that restrict agencies to evaluating vendors only on the listed factors when they cannot write a complete specification list implies that vendors "have incentives to shirk in the provision of those dimensions that are undervalued or are not explicitly requested in the RFP" (Greenstein, 1993:167), thus lowering the quality of the delivered good.

Williamson (1999) raises the hazard of probity as the fundamental hazard distinguishing some public transactions, such as foreign affairs. Williamson (1999:324) defines "probity transactions" as those having a strong need for loyalty (to the leadership and to the 
mission) and process integrity, while having low potential for operational cost hazards.

In this paper I try to show that probity, and the suspicion of lack of probity, is what drives much of the features of public contracting.

\section{Basic Framework of Third Party Opportunism}

The following provides a basic framework to understand the workings of third party opportunism and its impact on public contracting. Consider a political environment with four players:

a) Incumbent public agent - who is of uncertain quality (her predisposition to corruption being a good example), is responsible to choose the nature of the contract with the private party (which for simplicity can be considered as high power or low power), and which may or not involve a payment to her. ${ }^{24}$

b) Contractor - who could be a supplier or employee. His job is to accept or reject the contract offered by the incumbent public agent, and who will then share or not share the proceeds with the Incumbent.

c) Political competitor - the potential third party opportunist. This competitor's decision is whether to challenge the contract implementation. Challenges are, however, costly, so not all contract types will be challenged. The political competitor also is able to observe some signals concerning the realization of the contract which are not verifiable.

\footnotetext{
${ }^{24}$ It is easier to consider the public incumbent as a politician, that is, someone whose appointment to the position depends on the result of an election. The public incumbent, however, can also be a political appointee or a high level bureaucrat. All that is necessary is that she wants to remain in her position, for which she will need the support of higher level public agents and/or the public at large.
} 
d) The Public (which could be considered also as the court), who will, based on the actual realization of the contract and the challenge of the political competitor decide to retain the incumbent or to replace her by the political competitor (if the challenge took place). ${ }^{25}$

In this environment it is straightforward to show that low power incentives will be preferred by public incumbents. By relating payments to verifiable incurred costs, low power contracts limit the potential for successful political challenges. Contracts with low power incentives, however, may generate less social benefits, or be more costly to the public, but avoid the potentially negative political consequences of high power incentive contracts. Similarly, high power incentives do not provide the same benefits they could provide in private transactions. Challenges have also risks to the private party. In fact, challenges may impede, ex-post, the payment of high power compensation when it is due. Thus, third party opportunism also increases the risk to the private agent of transacting with the state.

The response to third party opportunism for both the incumbent public agent and the private transacting party is to provide low power contracts, to increase the degree of contract specificity, to limit the potential discretion granted to the public agent, and to increase procedural rigidity. Since the potential for third party opportunism increases with complexity, complex public contracting projects would then have more contractual rigidities than simpler public contracts. ${ }^{26}$ Rigidity, however, when combined with complexity, will increase conflict. The potential for conflict, together with the potential for third party opportunism, then, favors low power incentives. High power incentives

\footnotetext{
${ }^{25}$ The decision of the "public" will also depend on the performance of pro-incumbent interest groups.

${ }^{26}$ This result is consistent with Bajari and Tadelis (2001).
} 
simply may not be implementable given the potential for third party opportunism and the expected level of contractual conflict.

Thus, third party opportunism limits the potential for "relational public contracting." Public agencies will have difficulty entering into a close relation with a supplier, in which contract adaptation takes place without formal renegotiations, and/or litigation.

Furthermore, public contracting will not only be more complex, involving multiple rules and procedures, but will also be more subject to litigation. The added complexity required to limit the potential for third party opportunism will make public contracting look 'inefficient.' This inefficiency, however, does not pass Williamson’s (1999) remediableness test. In other words, the perceived inefficiency of public contracting is an equilibrium response to its hazards, and in particular, to the hazard of third party opportunism, a defining feature of public contracting. In fact, to eliminate the alleged inefficiency, one could consider two options: one, to move the transaction within the public sphere completely, that is, to vertically integrate; second, to drive it off the public and into the private sector. Consider, first, moving the transaction within the public sphere completely. Public vertical integration does not solve the "within the bureaucracy" contracting problems. In fact, similar types of concerns arise with the implementation of high power incentives within the bureaucracy itself. For the same reason that high power incentives are not appropriate for public contracting, high power incentives are not often appropriate for within the bureaucracy relations as high transfers 
to public employees will naturally raise probity questions, and will thus increase the risk of third party opportunism. ${ }^{27}$

Complete privatization of the government activity may not be feasible either. There is a public 'sphere of action' in which the government is the party best suited to engage in the transaction (Williamson 1999). Privatizing key policy making aspects of a nation, for example, may expose the nation to serious probity hazards. Thus, the undertaking of basic public policies will have to be undertaken by Government, and that would naturally require an interface with the private sector - that is, public contracting.

Furthermore, most public contracts would be even less efficient if brought completely within the public sphere. That the state is more "inefficient" in computer procurement than the private sector and has complex and rigid procurement procedures (Greenstein 1993) does not mean that the government should be in the business of making computers.

Thus, whether public contracting is, or not, inefficient cannot be inferred from the observation that it does not replicate private contracting. A proper comparison must be institutionally consistent and pass the Williamson's remediableness test. That can only be assessed on a case by case basis.

The potential for third party opportunism, furthermore, may be exacerbated by the nature of the institutional environment in which the public contract takes place. To thrive, third

\footnotetext{
${ }^{27}$ There are many instances, though, of the introduction of some type of high power incentives in bureaucracies. For example, Mexico's higher bureaucratic echelon under the PRI has traditionally been composed of a high paid technocracy, linked by a network of personal and political relations to the members of cabinet. As a consequence, career advancement has been based on informal norms of reciprocity and loyalty, where bad performance implies disloyal behavior, leading to discontinuation either right away or when the bureau chief moves to another position. See, Grindle (1977).
} 
party opportunism requires some political contestability and fragmentation. Although internal party politics could provide the environment for fragmentation, and for the type of political displacement required for third party opportunists to prosper, centralized party power limits the upward mobility of political mavericks, and thus the potential for internal third party opportunists. ${ }^{28}$ On the other hand, political instability, the caldron where governmental opportunism thrives, is also conducive for third party opportunism as the cost of removing incumbent politicians falls. In the middle, between stable centralized party control and rampant political instability, is where most of the world democracies fall. "Open access" states, following the nomenclature introduced by North, Wallis and Weingast (2006), naturally facilitate the development and organization of third party interest groups. In these societies, public policies become de-personalized, and governments are constrained in their ability to limit - whether by withdrawing funding, political harassment or direct violence - the development and organization of such groups. It is in these societies where the threat of third party opportunism becomes more credible, as such challenges may not be easily covered up by side payments or the direct threat of the recourse to violence. In "natural" states, following again North, Wallis and Weingast (2006) nomenclature, the public agent may have more instruments at her disposal to quash such challenges, and thus, it could be argued that her ability to overcome a third party challenge is increased.

\footnotetext{
${ }^{28}$ Two interesting parallel examples are the demise of the PRI and the LDP in Mexico and Japan respectively. Both parties controlled their respective polities for more than half a century, providing internal party mechanisms for resolution of public conflicts, as well as for the rotation, displacement and succession of public agents. The framework provided in this paper predicts that public contracting in Mexico and Japan became much more cumbersome and rigid since then. This is a topic for future research.
} 
This discussion, then, suggests that third party opportunism and governmental opportunism may not appear in similar circumstances. While governmental opportunism requires the existence of important sunk investments, such is not the case for third party opportunism. Third party opportunism may appear even when the contractor may move its assets costlessly elsewhere. ${ }^{29}$ Furthermore, while the potential for governmental opportunism requires an institutional environment with few institutional limitations to governmental discretion, the essence of "natural" states, the potential for third party opportunism is limited in such environments by the same discretionary ability of governments. Third party opportunism, then, would be more effective in open access states, thus suggesting that public agents would adapt public contracting further away from relational contracting in "open access" than in "natural" states.

In sum, public contracting is plagued by third party and governmental opportunism. While the institutional environment most propitious for the development of both types of opportunism differ and so differ the nature of transactions which may generate each, the framework provided here suggests that both types of hazards interact in increasing the specificity and rigidity of public contracts causing difficulties in adapting to shocks and leading to low-powered incentives. Similarly, both types of hazards, and their combination, lead to more "inefficient" termination of public than private contracts. These "inefficiencies" persist in equilibrium, and thus public contracting cannot be simply compared to private contracting, nor can the standard measure of performance

\footnotetext{
${ }^{29}$ In this case, the contractor has less to fear from the consequences of third party opportunism, but that is not the case for the public agent.

${ }^{30}$ This, however, does not mean that in "natural states" public contracting will be relational. In such states, public contracting is subject to governmental opportunism requiring its types of own adaptations.
} 
from private contracting be applied to public contracts. With this in mind, I proceed to analyze the implications of the framework to the use of concession contracts as regulatory instruments.

\section{An Application to Concession Contracts}

Concession contracts are part of the general set of licenses and permits through which states grant the right to a private organization to undertake a particular public-service activity. Concession contracts differ from other types of legal instruments in that while taking the form of operating licenses, they tend to embed the basic regulatory framework that will guide their evolution as it relates to basic features such as prices, quality, penalties, termination and the like. In that sense, the state that selects to grant a concession contract in essence is embedding the regulatory framework within a formal contract.

Concession contracts, then, differ from simple operating licenses, such as those common in the United States, as the latter are silent about the regulatory framework, leaving the management of the terms of operation of the licensee to other instruments, such as administrative procedures or specific legislation. ${ }^{31}$ Since including the regulatory framework within the license makes it more rigid, as significant changes in the regulatory framework requires either the consent of the concessionaire or a judicial decision, the natural question to ask is why a state chooses such a restrictive legal instrument.

In Spiller (1996a) I provide a theory of regulatory instrument choice based on the need for regulatory credibility given the nature of the institutional environment in which the

\footnotetext{
${ }^{31}$ See, Spiller (1996a) for a discussion of this issue.
} 
investment is undertaken. Concession contracts, then, arise as a mode for organizing provision of public services precisely because regulation by contracts sets limits to unilateral regulatory changes, and by doing that, it mitigates the potential for governmental opportunism (Levy and Spiller, 1994). In particular, regulation by contract is preferred in sectors with a high level of sunk assets (e.g., water, transport, natural gas, and electricity distribution), in politically unstable environments, and when regulation by law does not provide enough credibility to protect the investments of the service providers. In these cases the providers are vulnerable to governmental opportunism, and so private service providers will not enter the market or demand too high a premium on services under direct regulation. Concession contracts, by creating an individualized regulatory framework for the investments at hand, limit such opportunism.

The choice of regulatory contracts shows the inexorable trade-off between commitment and flexibility (Spiller 1996a). To be credible, a regulatory contract must be specific i.e., it must lay out in detail how the parties will deal with each eventuality. However, adjustments in the relationship require flexibility in the contract, which in turn requires that the contract be complex. Complexity is limited by administrative capability and negotiation costs (which depends on differences among potential investors and political incentives).

Concession contracts are rigid by "origin”. A flexible concession contract that grants substantial discretion to the state would fail to provide the required commitment, and thus would not be seen by the investor as mitigating the risk of governmental opportunism. Thus, concession contracts are born with less flexibility than normal private contracts. 
They are also not "relational contracts." In fact, adaptations to shocks seldom involve serious contractual deviations without triggering formal contractual adaptations. ${ }^{32}$ In fact, Guasch (2004) finds that from a total of 942 concessions granted in Latin American countries from the mid-1980s, by year 2000 a full $42 \%$ of them were renegotiated.

Figure 2 below shows the distribution across sectors, showing that most transport and water concession contracts were renegotiated.

Figure 2: Latin America Concession Contracts Renegotiated 1985-2000

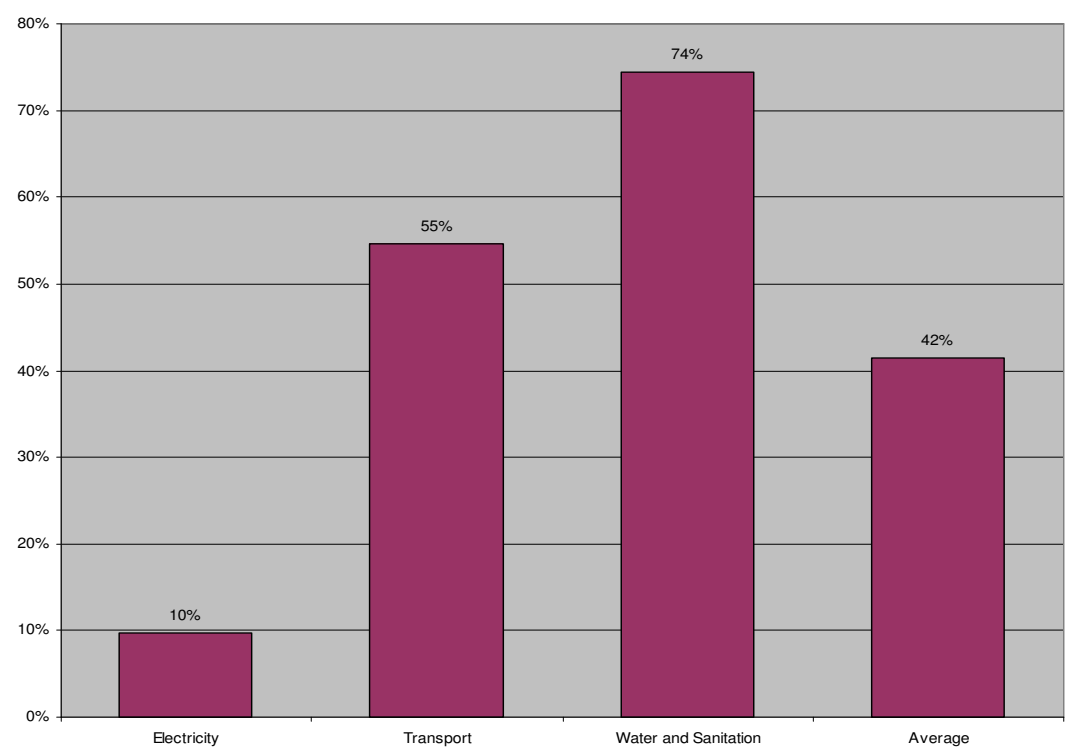

Source: Guasch (2004).

The large percentage of formally renegotiated contracts is only surprising if we look at it from the perspective of 'relational contracts.' But regulatory adaptations should not be surprising. Most concession contracts should be adapted over time, as by nature, these contracts are long term and incomplete. As a consequence, it is unreasonable to expect that through the long life of these concessions, there will be no economic (e.g., an

\footnotetext{
${ }^{32}$ In a sense, it is possible to say that the frequency of contract renegotiation may provide concessions a 'relational' quality.
} 
unexpected increase in external or internal costs) or political shocks (e.g., new political needs) that would call for a change in the agreed terms of the contract. An unadjusted contract may lead to unproductive actions or even default, generating unnecessary social losses.

In fact, while adaptation to new realities is necessary, informal adaptation, whereby the parties agree to deviate from the terms of the concession contract without formal renegotiation raises the risk of third party opportunism. As a consequence, adaptation, if needed, would mostly be done by formal renegotiation.

Here is, though, where governmental and third party opportunism interact. Formal renegotiation raises the risk of third party opportunism, as the whiff of corruption can immediately be sensed. Thus, to generate a formal renegotiation, the shock has to be large enough that the need for adaptation becomes clear to lay observers.

Long term concessions are exposed to different types of economic shocks. Internal shocks arise early in the life of the concession when concessionaires are granted the use of existing assets whose working conditions are difficult to ascertain. This is mostly the case in waterworks concessions, where operators are granted the use of a waterworks often without updated maps detailing routes, inventory of type of equipment, clients, and so on. In fact, most water concessions get renegotiated in the initial two years.

External shocks are simply the normal types of demand and cost changes (devaluations, drastic increase in input costs not covered in the contract, etc) that may drastically impact the viability of the concession. This could be the case if the contract introduces high power incentives features, such as annual payments to the government for the right to 
operate the concession, minimum investment levels, or fixed prices over long periods of time. ${ }^{33,34}$ These conditions may become very onerous to implement if an economic shock lowers revenue expectations after the contract has been signed. By contrast, a regulatory mechanism characterized by lower-powered incentives, such as rate-of-return regulation, is less likely to trigger the need to renegotiate, as it generates adaptation more naturally.

Lack of adaptation following a shock that threatens the viability of the concession may in fact trigger contract termination. While termination may be "socially inefficient," 35 it may be politically preferable for the public agent than bearing the third party opportunism risks associated with renegotiating the contract. ${ }^{36}$

All other things being equal, it is reasonable to expect that the larger the investments undertaken in relation to future network expansion needs, the higher the government's incentive to terminate the concession (Troesken 1997), both because of governmental opportunism and because of the difficulties of renegotiating given third party opportunism hazards. Given the risk of early termination, concession contracts normally provide for very specific and explicit compensation at termination, whether early or normal. The degree of specificity of these clauses is obvious: the greater the ability of

\footnotetext{
${ }^{33}$ There are various types of price cap regulatory schemes. The UK style involves tariff reviews every five years. Others may set prices without a fixed term for review, relying instead on the initiation of extraordinary tariff reviews.

${ }^{34}$ In fact, Guasch et al (2003) show that the probability of renegotiation in Latin America increases with the presence of price caps, financial commitments and large scale investment requirements.

${ }^{35}$ The concession would need to be taken over by the government, and then transferred again to a private operator, who, this time will not accept without further guarantees of proper governmental behavior.

${ }^{36}$ Termination may also be the result of governmental opportunism. An economic shock may enable the government to expropriate the quasi-rents physically (via termination) that could not be obtained financially (by renegotiating on more favorable terms).
} 
the state to manipulate the compensation, the higher the government's incentive to terminate. $^{37}$

Although there are inherent ${ }^{38}$ and institutional limits to governmental opportunism, third party opportunism may not be subject to these limitations. Even in contractual circumstances where the potential for governmental opportunism has been limited by expectations of future investments or institutional limitations, third party opportunism may still trigger "inefficient" contract termination.

Consider, for example, waterworks in the U.S. A large number of municipalities across the United States use concession contracts to operate and manage their water works. ${ }^{39}$ Not all contracts, though, are for city-wide service, with most covering only partial operations, such as operation of a particular pumping or treatment plant, or the provision of billing services (Water Science and Technology Board, 2002). These contracts are long term, often dealing with highly complex physical environments. ${ }^{40}$ These contracts assign risks to the contractor and the city in highly complex and sophisticated fashions, providing for cost escalation clauses, and for renegotiation facing a large scale shock such a natural disaster. ${ }^{41}$ The transfer of existing operations to a private contractor is,

\footnotetext{
${ }^{37}$ Governments may still attempt to manipulate compensation via the introduction of 'counter-claims' although that would naturally lead to litigation.

${ }^{38}$ The government may benefit from a reputation for being a good contracting partner, especially if it takes the long-term view. There may also be a financial cost of termination, including contractual termination clauses, the rules of contract law generally, or even international law.

${ }^{39}$ Some commentators put the number of water systems operated by private operators in the United States above 1,100 (see, for example, Arrandale, Tom, 2003. "Foreign Faucet," Governing. Available at $<$ http://www.governing.com/archive/2003/jun/water.txt $>$ ).

${ }^{40}$ This observation is based on a set of contracts obtained via directly contacting the municipalities and asking for copies of all such contracts they may have.

${ }^{41}$ The 1997 Seattle Public Utilities Treatment Plant Contract, is such an example. See Appendix C to Water Science and Technology Board (2002).
} 
though, as complex in the United States as elsewhere. ${ }^{42}$ Consider, for example, the breakdown of the Atlanta waterworks contract. In January 2003, the City of Atlanta terminated what was then a twenty two year management and operation contract of the whole waterworks system of Atlanta, only four years after its transfer. Right after the transfer the parties entered into conflicts on the costs required to meet the standards agreed upon in the contract. United Water, the operator, claimed that much of the baseline data were inaccurate and thus, the targets and annual fees agreed upon were unrealistic, forcing it to lose $\$ 10$ million a year out of a $\$ 20.8$ million/year contract. ${ }^{43}$ Renegotiation, then, would have to involve a substantially higher per year fee, as well as a modification of the service targets. The City, however, preferred to take back the contract at a cost of $\$ 40$ million/year - against the $\$ 22$ million/year of the contract, rather than having to handle the public criticism of its management of the contract. Following the reasoning in this paper, renegotiation would have been "in neither party's interest."44 It would not have been in the City's interest as it would be extremely difficult to explain that a contract drafted and crafted by the City just a few years ago was in such seeming disarray that it requires a substantial fee increase. For the City it would be much easier to blame all problems on the operator's bad performance. Similarly, it would not have been in the operator's interest, as, given the public perception of wrongful operator performance, it would be difficult to expect that the renegotiated contract would fully

\footnotetext{
${ }^{42}$ See discussion of the Aguas del Aconquija contract termination above.

${ }^{43}$ See, "Water Privatization Becomes a Signature Issue in Atlanta." The Center for Public Integrity. Available at < http://www.icij.org/Content.aspx?src=search\&context=article\&id=55 >. See, also, "As Cities Move to Privatize Water, Atlanta Steps Back," Great Lakes Article, by Douglas Jehl, February 18, 2003. Available at < http://www.greatlakesdirectory.org/zarticles/021803_great_lakes.htm>.

${ }^{44}$ See “As Cities Move to Privatize Water...."
} 
compensate it. At the end, the parties ended the contract "amicably."45 The contract termination, however, was preceded by a series of corruption allegations involving an agreement to grant a $\$ 4$ million/year for 17 years payment increase following the operator's request for $\$ 80$ million compensation for work not included in the contract, ${ }^{46}$ and allegations that the Mayor had business relations with a competing water operator. ${ }^{47}$

The Atlanta case is an example of a contract falling apart not because of governmental opportunism - as seems to have been the case in Aguas del Aconquija, but rather by the inability of the parties to draft and implement contracts with sufficiently flexibility that can adapt to uncertain operating circumstances. Instead, the parties entered into a highly inflexible contract, forcing them to renegotiate or terminate. The City, however, was unwilling to pay the political price of renegotiation. The main thrust of this paper is that contract inflexibility is inherent to public contracts, and that, facing the potential for third party opportunism, large shocks may trigger termination and/or litigation rather than renegotiation.

\section{Regulatory Implications}

This analysis has some implications for regulation by contract. Regulation by contract must limit high cash-flow fluctuations, suggesting that rate-of-return regulation will be better suited to concession contracts than price cap regulation. It must also limit

\footnotetext{
${ }^{45}$ The termination involved a net payment of $\$ 5$ million from United Water to the City. See, Joint News Release: City of Atlanta and United Water Announce Amicable Dissolution of Twenty-Year Water Contract, January 23, 2003. Available at $<$ http://www.unitedwater.com/pr012403.htm $>$.

${ }^{46}$ The agreement seems to have been signed by the then Mayor Bill Campbell in a series of letters, who later on the City attorneys claimed were invalid, and which Mr. Campbell claimed did not sign. See, "Water Privatization Becomes..."

${ }^{47}$ Ibid.
} 
investment requirements. These have not worked well in practice and instead direct subsidies may provide better incentives to invest in low-income sectors. Regulation must also provide a well-defined system of penalties for quality and limit transfer of concessions based on annual payments or lowest prices. However, the reductions in incentives this regulatory system creates may not necessarily be harmful. Gilbert and Riordan (1995) argue that in environments with low technological change, high-poweredincentive regulation is not that necessary.

\section{Final Comments}

This paper argues that public contracting is plagued by third party and governmental opportunism. Providing for both types of hazards results in highly specific and rigid contracts causing difficulties in adapting to shocks and leading to low-powered incentives. Nevertheless, there is likely to be more "inefficient" termination of public than private contracts. High contract specificity, termination penalties and jurisdictional arrangements arise as safeguards. These "inefficiencies" persist in equilibrium, and thus public contracting cannot be simply compared to private contracting, nor can the standard measure of performance from private contracting be applied to public contracts.

This framework has direct implications for the study of regulation. In particular, this framework suggests the need to reconsider the use of high-powered incentives in concession contracts and rethink the beauty of simple, less theoretically "efficient" contracts that are likely to be more conducive to long term sustainability (Levy and Spiller 1994). This framework also has direct implications for other types of public contracting, such as the organization of the bureaucracy, a subject left for another paper. 


\section{References}

Bajari, Patrick and Steve Tadelis, 2001. "Incentives versus transaction costs: a theory of procurement contracts," 32 Rand Journal of Economics, pp: 387-407.

Baker, George, Gibbons, Robert and Murphy, Kevin J. 2001, "Bringing the Market inside the Firm?" 91 American Economic Review, 2001, pp. 212-218. . 2002. "Relational Contracts and the Theory of the Firm" 117(1), The Quarterly Journal of Economics, pp. 39.

Bernard, T., B. Gallagher, R. Bate and H. Wilson, 2004. "CMMI Acquisition Module (CMMI-AM) Version 1.0, Technical Report CMU/SEI-2004-TR-001, February.

Coase, Ronald. 1964. "The Regulated Industries: Discussion," 54 American Economic Review, 194-197.

Dal Bó, Ernesto and Rafael Di Tella. 2006. "Plata o Plomo? Bribe and Punishment in a Theory of Political Influence,” 100 American Political Science Review, pp:41-53.

deFigueiredo Rui, Pablo T. Spiller and Santiago Urbiztondo. 1999. "An Informational Perspective on Administrative Procedures," 15 Journal of Law, Economics \& Organization, pp:283-305.

Gilbert, Richard J. and Riordan, Michael H. 1995. "Regulating Complementary Products: A Comparative Institutional Analysis." 26 RAND Journal of Economics, pp. 243-256.

Greenstein, Shane. 1993. "Procedural Rules and Procurement Regulations: Complexity Creates Trade-Offs." 9 Journal of Law, Economics and Organization, pp. 159-179.

Greif, Avner. 1993. "Contract Enforceability and Economic Institutions in Early Trade: The Maghribi Traders' Coalition," 83 American Economic Review, 525-548.

Grindle, Merilee S. 1977. "Patrons and Clients in the Bureaucracy: Career Networks in Mexico," 12 No. 1, Latin American Research Review, 37-66

Guasch, J. Luis, 2004. Granting and Renegotiating Infrastructure Contracts: Doing It Right, Washington, DC: The World Bank Institute.

, Jean-Jacques Laffont, and Stéphane Straub, 2003. "Renegotiation of Concession Contracts in Latin America," The World Bank Policy Research Working Paper 3011.

Kelman, Steven 1990. Procurement and Public Management: The Fear of Discretion and the Quality of Government Performance. Washington, D.C.: American Enterprise Institute Press.

Laffont, Jean-Jacques and Tirole, Jean. A Theory of Incentives in Procurement and Regulation. 1993. 
Landa, Janet T. 1981. "A Theory of the Ethnically Homogeneous Middleman Group: An Institutional Alternative to Contract Law," 10 Journal of Legal Studies, pp:349-362.

Levy, Brian and Spiller, Pablo T. 1994. "The Institutional Foundations of Regulatory Commitment: A Comparative Analysis of Telecommunications Regulation." 10(2) Journal of Law, Economics and Organization, pp. 201.

Macaulay, Stewart, 1963. "Non-Contractual Relations in Business: A Preliminary Study," 28 American Sociological Review, pp: 55-67.

MacNeil, Ian R. 1974. "Restatement (Second) of Contracts and Presentation," 60 Virginia Law Review, pp: 589-610.

. 1978. "Contracts: Adjustment of Long Term Economic Relations Under Classical, Neoclassical and Relational Contract Law," 72 Northwestern University Law Review, pp:854-905.

Marshall, Robert C., Michael J. Meurer and Jean-François Richard, 1991. "The Private Attorney General Meets Public Contract Law: Procurement Oversight by Protest.” 20 Hofstra Law Review, pp. 1-71.

. 1994. "Curbing Agency Problems in the Procurement Process by Protest Oversight," 25 Rand Journal of Economics, pp: 297-318.

McCubbins, Matthew and Thomas Schwartz, 1984. "Congressional Oversight Overlooked: Police Patrols versus Fire Alarms," 28 American Journal of Political Science, pp: 165-179.

McCubbins, Matthew, Roger Noll and Barry Weingast 1987. "Administrative Procedures as Instruments of Political Control," 3 Journal of Law, Economics and Organization, pp 243-277.

. 1989. "Structure and Process, Politics and Policy: Administrative Arrangements and the Political Control of Agencies," 75 Virginia Law Review, pp: 431-482.

Milgrom, Paul and Roberts, John. 1988 "An Economic Approach to Influence Activities in Organizations," 94 American Journal of Sociology, pp: S154-S179.

Milgrom, P., North, D. and Weingast, B. 1990, "The Role of Instittutions in the Revival of Trade: The Law Merchant, Private Judges and the Champagne Fairs", Economics and Politics, Vol. 2, pp:1-23.

North, D., J.J. Wallis and B.R. Weingast, 2006. "A Conceptual Framework for Understanding Recorded Human History,” NBER Working Paper 12795.

Richman, Barak. 2006. "How Community Institutions Create Economic Advantage: Jewish Diamond Merchants In New York," 31 Law and Social Inquiry, 383-420. 
Savedoff, William, and Pablo Spiller. 1999. Spilled Water: Institutional Commitment in the Provision of Water Services in Latin America, Washington DC: Interamerican Development Bank.

Spiller, Pablo. T. 1996a. "A Positive Political Theory of Regulatory Instruments: Contracts, Administrative Law or Regulatory Specificity?," 69 Southern California Law Review, pp: 477-515. 421-452.

. 1996b. "Institutions and Commitment," 5 Industrial and Corporate Change, pp:

Telser, Lester. 1981. "A Theory of Self Enforcing Agreements," 53, Journal of Business, 27-44.

Troesken, Werner, 1997. Why Regulate Utilities? The New Institutional Economics and the Chicago Gas Industry, 1849-1924, Ann Arbor: University of Michigan Press.

Water Science and Technology Board, 2002. Privatization of Water Services in the United States: An Assessment of Issues and Experience. Washington DC: National Academy Press.

Williamson, O. E. 1975. Markets and Hierarchies: Analysis and Antitrust Implications, New York: Free Press.

. 1979, "Transaction-Cost Economics: The Governance of Contractual Relations," 22 Journal of Law and Economics, pp: 233-261.

. 1983, "Credible Commitments: Using Hostages to Support Exchange." 73

American Economic Review, pp. 519-540.

. 1985. The Economic Institutions of Capitalism. New York: Free Press.

1996. The Mechanisms of Governance. New York, Oxford University Press.

. 1999. "Public and Private Bureaucracies: A Transaction Cost Economics

Perspectives." 15 Journal of Law Economics and Organization, pp. 306-42.

. 2002. "The Lens of Contract: Private Ordering," 92 American Economic Review, pp:438-443.

2005. “The Economics of Governance," 95 American Economic Review, pp:1-18. 